GA-A23900

\title{
ADVANCED HIGH PERFORMANCE SOLID WALL BLANKET CONCEPTS
}

C.P.C. WONG, S. MALANG, S. NISH 


\section{DISCLAIMER}

This report was prepared as an account of work sponsored by an agency of the United States Government. Neither the United States Government nor any agency thereof, nor any of their employees, makes any warranty, express or implied, or assumes any legal liability or responsibility for the accuracy, completeness, or usefulness of any information, apparatus, product, or process disclosed, or represents that its use would not infringe privately owned rights. Reference herein to any specific commercial product, process, or service by trade name, trademark, manufacturer, or otherwise, does not necessarily constitute or imply its endorsement, recommendation, or favoring by the United States Government or any agency thereof. The views and opinions of authors expressed herein do not necessarily state or reflect those of the United States Government or any agency thereof. 
GA-A23900

\title{
ADVANCED HIGH PERFORMANCE SOLID WALL BLANKET CONCEPTS
}

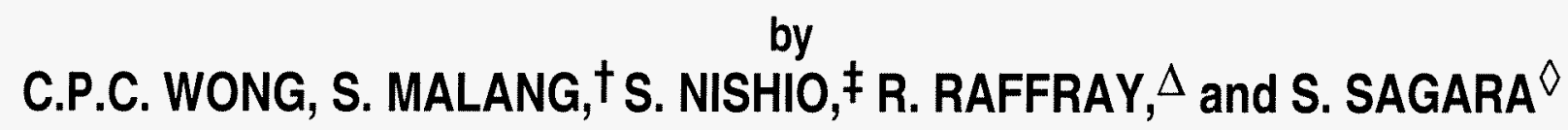

This is a preprint of a paper presented at the 6th International Symposium on Fusion Nuclear Technology, San Diego, California, April 7-12, 2001, and to be published in the Proceedings.

\author{
tForschungszentrum Karlsruhe \\ ҒJapanese Atomic Energy Reseach Institute \\ $\triangle_{\text {FERP, University of California, San Diego }}$ \\ $\vartheta_{\text {LHD Project }}$
}

\author{
Work supported by \\ the U.S. Department of Energy \\ under Contract DE-AC03-98ER54411
}




\begin{abstract}
First wall and blanket (FW/blanket) design is a crucial element in the performance and acceptance of a fusion power plant. High temperature structural and breeding materials are needed for high thermal performance. A suitable combination of structural design with the selected materials is necessary for D-T fuel sufficiency. Whenever possible, low afterheat, low chemical reactivity and low activation materials are desired to achieve passive safety and minimize the amount of high-level waste. Of course the selected fusion FW/blanket design will have to match the operational scenarios of high performance plasma. The key characteristics of eight advanced high performance FW/blanket concepts are presented in this paper. Design configurations, performance characteristics, unique advantages and issues are summarized. All reviewed designs can satisfy most of the necessary design goals. For further development, in concert with the advancement in plasma control and scrape off layer physics, additional emphasis will be needed in the areas of first wall coating material selection, design of plasma stabilization coils, consideration of reactor startup and transient events. To validate the projected performance of the advanced FW/blanket concepts the critical element is the need for $14 \mathrm{MeV}$ neutron irradiation facilities for the generation of necessary engineering design data and the prediction of FW/blanket components lifetime and availability.
\end{abstract}




\section{INTRODUCTION}

Advanced FW/blanket designs have always been aiming for adequate nuclear and high thermal performance, including the use of low activation materials. In recent years we have continued the development and application of $\mathrm{SiC}_{\mathrm{f}} / \mathrm{SiC}$ composite material for use with solid and liquid breeder materials. We continued to evaluate the use of $\mathrm{V}$-alloy with stagnant Li and selfcooled Flibe coolant options. We have also evaluated the use of refractory alloys and selected Walloys for further assessment. This paper presents eight advanced solid wall blanket designs with different combinations of structural, tritium breeding materials and cooling options. Key parameters of these advanced solid first wall designs are presented in Table 1. Summary descriptions are given on the configuration, performance characteristics, and identification of special features and critical issues. Subsequently, we comment on how these designs have satisfied the required and desirable attributes for the reactor design. Future needs and directions on the development of advanced FW/blanket designs are also provided in this paper. For a more complete review of $\mathrm{SiC}_{\mathrm{f}} / \mathrm{SiC}$ composite designs, readers are referred to the paper presented in this conference titled, "Progress in Blanket Designs Using $\mathrm{SiC}_{\mathrm{f}} / \mathrm{SiC}$ composites" [1]. It should be noted that we have selected a few recent FW/blanket concepts for comparison. Other well known advanced concepts like the $\mathrm{V}$-alloy Li-self-cooled FW/blanket concept have not been included in this paper. 
Table 1

Key design parameters of eight advanced FW/blanket designs

\begin{tabular}{|c|c|c|c|c|c|c|c|c|}
\hline & 1 & 2 & 3 & 4 & 5 & 6 & 7 & 8 \\
\hline & A-SSTR-2 & A-HCPB & TAURO & $\begin{array}{l}\text { ARIES- } \\
\mathrm{AT}^{1}\end{array}$ & $\mathrm{~V} / \mathrm{Li} / \mathrm{He}$ & W/Li/He & EVOLVE & FFHR-2 \\
\hline Application & Tokamak & Tokamak & Tokamak & Tokamak & Tokamak & Tokamak & Tokamak & Stellerator \\
\hline Pfusion, GW & 4 & 4.5 & 3 & 1.7 & 1.9 & 3.5 & 3.5 & 1 \\
\hline FW heat flux, MW/m² & 1.4 (ave.) & 0.6 (peak) & $\begin{array}{c}0.5 \text { (ave) } \\
0.69 \text { (peak) }\end{array}$ & $\begin{array}{l}0.26 \text { (ave) } \\
0.34 \text { (peak) }\end{array}$ & 0.34 & 2 (peak) & 2 (peak) & 0.09 \\
\hline $\begin{array}{l}\text { Neutron wall loading, } \\
M W / m^{2}\end{array}$ & 6 (ave.) & $\begin{array}{l}2.76 \text { (ave.) } \\
3.5 \text { (peak) }\end{array}$ & $\begin{array}{c}2 \\
2.8 \text { (peak) }\end{array}$ & 3.2 (ave) & 2.9 (ave) & 7 (peak) & 10 (peak) & 1.7 \\
\hline Structural material & $\begin{array}{l}\mathrm{SiC}_{f} / \mathrm{SiC} \\
\text { composite }\end{array}$ & $\mathrm{SiC}_{f} / \mathrm{SiC}$ & $\begin{array}{l}\mathrm{SiC}_{f} / \mathrm{SiC} \\
\text { composite }\end{array}$ & $\begin{array}{l}\mathrm{SiC}_{f} / \mathrm{SiC} \\
\text { composite }\end{array}$ & $\mathrm{V}-4 \mathrm{Cr}-4 \mathrm{Ti}$ & W-alloy & W-alloy & $\mathrm{V}-4 \mathrm{Cr}-4 \mathrm{Ti}$ \\
\hline FW thickness, mm & $4-6$ & 3 & 6 & $\begin{array}{c}4 \\
+1 \text { (armor) }\end{array}$ & 3 & 3 & 3 & 5 \\
\hline $\begin{array}{l}\text { Structural material } \\
T_{\text {max }} \text {-allowed, }{ }^{\circ} \mathrm{C}\end{array}$ & 1100 & 1300 & 1300 & 1000 & 700 & 1400 & 1400 & 750 \\
\hline $\begin{array}{l}\text { FW material, } K_{\text {th }} \\
W / m \cdot K\end{array}$ & $10-50$ & 15 & 15 & 20 & 35 & $\stackrel{85}{@}$ & $\begin{array}{c}85 \\
@ 1400 \mathrm{~K}\end{array}$ & 35 \\
\hline $\begin{array}{l}\text { Tritium breeder (neutron } \\
\text { multiplier) }\end{array}$ & $\underset{(\mathrm{Be})}{\mathrm{Li}_{2} \mathrm{TiO}_{3}}$ & $\begin{array}{l}\mathrm{Li}_{4} \mathrm{SiO}_{4} \\
(\mathrm{Be})\end{array}$ & $\begin{array}{l}\mathrm{Pb}-17 \mathrm{Li} \\
\text { (none) }\end{array}$ & $\begin{array}{l}\mathrm{Pb}-17 \mathrm{Li} \\
\text { (none) }\end{array}$ & $\begin{array}{c}\mathrm{Li} \\
\text { (none) }\end{array}$ & $\begin{array}{c}\mathrm{Li} \\
\text { (none) }\end{array}$ & $\underset{\text { (none) }}{\mathrm{Li}}$ & $\begin{array}{l}\text { Flibe } \\
(\mathrm{Be})\end{array}$ \\
\hline Fuel form & Pebbles & Pebbles & Liquid & Liquid & Liquid & Liquid & Liquid & Liquid \\
\hline $\begin{array}{l}\text { Coolant } \\
\text { (Pressure, MPa) }\end{array}$ & $\begin{array}{l}\mathrm{He} \\
(10)\end{array}$ & $\begin{array}{l}\mathrm{He} \\
(8)\end{array}$ & $\begin{array}{l}\mathrm{Pb}-17 \mathrm{Li} \\
(1.5)\end{array}$ & $\begin{array}{l}\mathrm{Pb}-17 \mathrm{Li} \\
\text { (1) }\end{array}$ & $\begin{array}{l}\mathrm{He} \\
(18)\end{array}$ & $\begin{array}{l}\mathrm{He} \\
(12)\end{array}$ & $\begin{array}{l}\text { Vaporized LI } \\
\quad(0.037)\end{array}$ & $\begin{array}{l}\text { Flibe } \\
(0.6)\end{array}$ \\
\hline $\begin{array}{l}\text { Tritium breeding ratio } \\
\text { (Li-6 enrichment) }\end{array}$ & $\begin{array}{l}1.37 \text { (local) } \\
\text { (natural) }\end{array}$ & $\begin{array}{c}1.09 \\
\text { "3-D" } \\
\text { (optimízed) }\end{array}$ & $\begin{array}{l}1.37 \\
\text { (local) } \\
(90 \%)\end{array}$ & $\begin{array}{c}1.1 \\
\text { "3-D" } \\
\text { (natural) }\end{array}$ & $\begin{array}{l}1.4 \text { (local) } \\
\text { (natural) }\end{array}$ & $\begin{array}{c}1.43 \text { (local) } \\
(35 \%)\end{array}$ & $\begin{array}{c}1.33 \text { (local) } \\
\text { (natural) }\end{array}$ & $\begin{array}{c}1.4 \\
\text { (local) } \\
(50 \%)\end{array}$ \\
\hline Coolant $\mathrm{T}_{\text {in }},{ }^{\circ} \mathrm{C}$ & 600 & 350 & 650 & 654 & 400 & 800 & 1100 & 450 \\
\hline Coolant $T_{\text {out }}{ }^{\circ} \mathrm{C}$ & 900 & 700 & 860 & 1100 & 650 & 1100 & 1200 & 550 \\
\hline Power conversion cycle & $\mathrm{CCGT}^{2}$ & $\mathrm{CCGT}^{2}$ & $\mathrm{CCGT}^{2}$ & $\mathrm{CCGT}^{2}$ & $\mathrm{CCGT}^{2}$ & $\mathrm{CCGT}^{2}$ & $\mathrm{CCGT}^{2}$ & $\mathrm{CCGT}^{2}$ \\
\hline$\eta_{\text {th }} \%$ & 51 & 44.8 & $>47$ & 58.5 & 46 & 57.5 & 58 & 45 \\
\hline
\end{tabular}

${ }^{1}$ For ARIES-AT the surface heat flux used for temperature and stress calculation was $0.7 \mathrm{MW} / \mathrm{m}^{2}$.

${ }^{2}$ Closed Cycle Gas Turbine 


\section{DESIGN SUMMARY}

1. The A-SSTR-2 is a compact power reactor $(\mathrm{Ro}=6.2 \mathrm{~m}, \mathrm{a}=1.5 \mathrm{~m})$ with a fusion power output of $4 \mathrm{GW}$. Its $\mathrm{FW} /$ blanket is a $\mathrm{SiC}_{\mathrm{f}} / \mathrm{SiC}$ composite, $\mathrm{Li}_{2} \mathrm{TiO}_{3}(\mathrm{Be})$ pebble breeder, helium-cooled design [2]. It has an average neutron wall loading of $6 \mathrm{MW} / \mathrm{m}^{2}$ and an average heat flux of $1.4 \mathrm{MW} / \mathrm{m}^{2}$. With helium at $10 \mathrm{MPa}$, the projected Brayton cycle thermal efficiency is $51 \%$. The first wall and blanket small module configuration is shown in Fig. 1. The coolant helium flows towards the first wall from the outer annulus of the concentric coolant tube and cools the first wall. It then turns and cools the Be and the breeder pebble zones while exiting the blanket module from the inner channel of the concentric coolant tube. Key parameters of the design are presented in Table 1. In addition to the development need of the $\mathrm{SiC}_{\mathrm{f}} / \mathrm{SiC}$ composite structural material, the study also identified the need to have high thermal conductivity of $50 \mathrm{~W} / \mathrm{m}-\mathrm{K}$ for $\mathrm{SiC}_{\mathrm{f}} / \mathrm{SiC}$ when the material is also used to handle the high surface heat flux at the divertor.

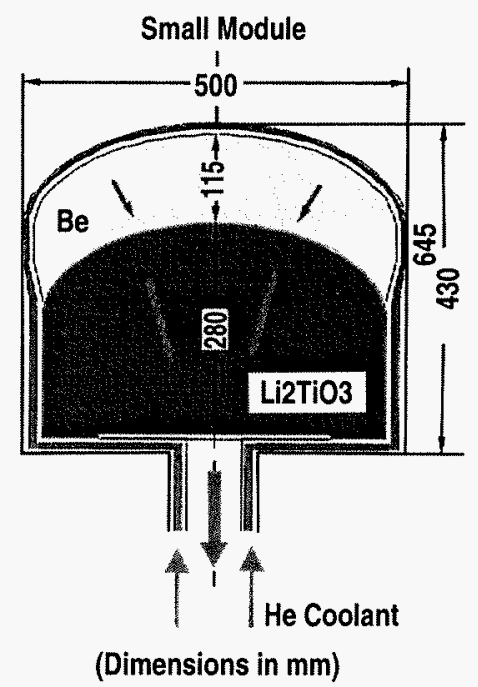

Fig.1. A-SSTR-2 FW/blanket module.

2. The A-HCPB FW/blanket [3] is proposed as a candidate in the European program as a DEMO relevant blanket. It is a $\mathrm{SiC}_{\mathrm{f}} / \mathrm{SiC}$ composite, $\mathrm{Li}_{4} \mathrm{SiO}_{4}$ ceramic pebble breeder, 
helium-cooled design, with a projected thermal efficiency of $\sim 45 \%$. Key design parameters are presented in Table 1. The FW/blanket configuration is shown in Fig. 2, which shows a different approach than for the A-SSTR-2 FW/blanket design. For the A-HCPB design there are two $\mathrm{SiC}_{\mathrm{f}} / \mathrm{SiC}$ components: a helium-cooled box formed by a series of parallel tubes forming the first wall, and $\mathrm{SiC}_{\mathrm{f}} / \mathrm{SiC}$ cooling plates formed by long meanders separating the breeder ceramic pebbles from the Be pebbles. Since the helium coolant is at $8 \mathrm{MPa}$, a burst disk is proposed to handle the accidental situation of highpressure coolant leakage, which may cause pressurization of the blanket module.

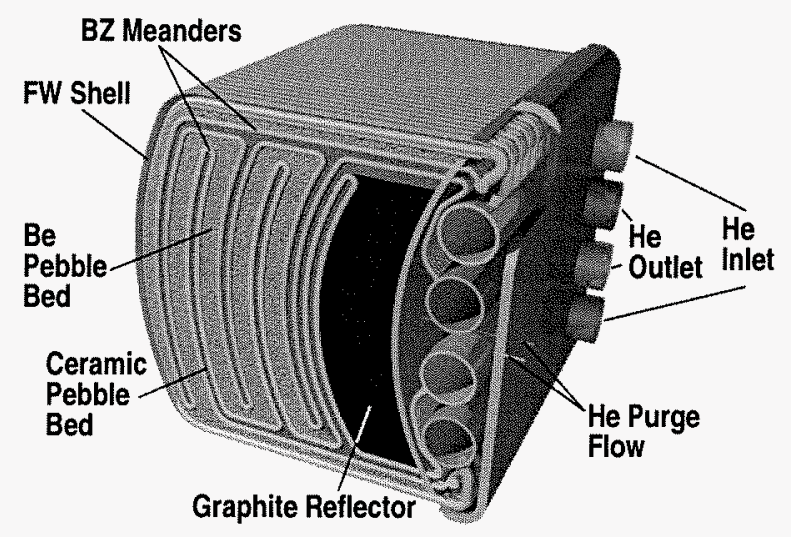

Fig. 2. Advanced HCPB FW/blanket.

3. The TAURO design [4] is based on the specification from the SEAFP study [5]. It is a $\mathrm{SiC}_{\mathrm{f}} / \mathrm{SiC}$ composite, self-cooled $\mathrm{Pb}-17 \mathrm{Li} \mathrm{FW} /$ blanket design, with a projected thermal efficiency of $>47 \%$. This combination of materials avoids the development of electrically insulating wall coatings necessary for the metallic structure and conducting fluid selfcooled design. It also can be designed to lower system pressure, and the geometry is more compact by eliminating the helium void fraction when compared to the high-pressure helium-cooled designs. Parameters of this design are presented in Table 1. The TAURO FW/blanket configuration is shown in Fig. 3. Each outboard segment is poloidally divided into several straight modules, attached on one common thick back-plate but cooled independently. The feeding pipes are located behind the module. The coolant 


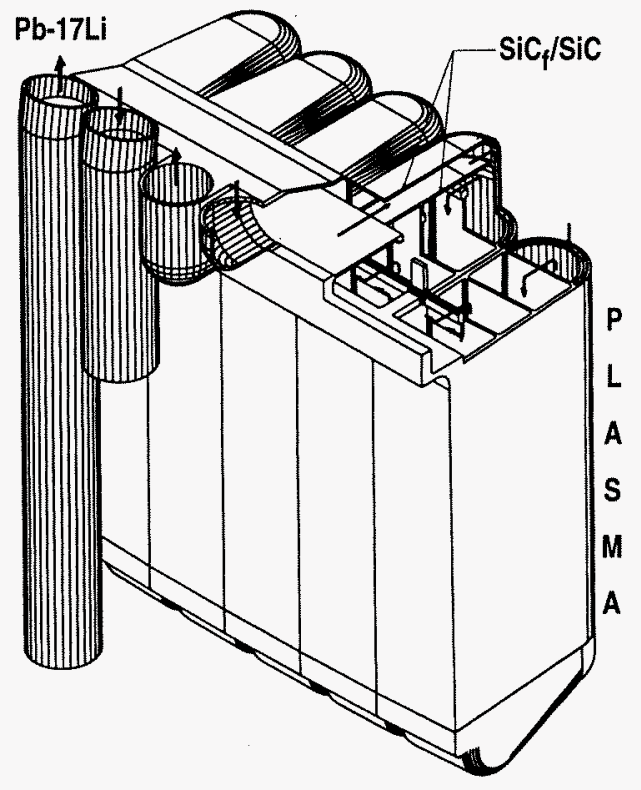

Fig. 3. TAURO FW/blanket design, outboard module.

enters the inlet collector through a single tube and is divided into five sub-flows, one for each sub-module. The $\mathrm{Pb}-17 \mathrm{Li}$ flows at first poloidally downward in a thin channel located just behind the FW, makes a U-turn at the bottom into a second channel and flows up, and then down into the outlet collector. During the design evaluation, in order to meet all the stress limits, exploratory work was done to vary the module height. For a module height of $2 \mathrm{~m}$, both von Mises and normal stress limits can be satisfied for a surface heat flux of $0.6 \mathrm{MW} / \mathrm{m}^{2}$. In addition to the development need for the $\mathrm{SiC}_{\mathrm{f}} / \mathrm{SiC}$ composite structural material, the issue of compatibility between $\mathrm{SiC}_{\mathrm{f}} / \mathrm{SiC}$ composite material with $\mathrm{Pb}-17 \mathrm{Li}$ at high temperature is being addressed.

4. The ARIES-AT FW/blanket is another $\mathrm{SiC}_{\mathrm{f}} / \mathrm{SiC}$ composite, $\mathrm{Pb}-17 \mathrm{Li}$ cooled design [6], with a thermal efficiency of $58.5 \%$. The FW/blanket configuration is shown in Fig. 4 and key design parameters are presented in Table 1 . The first row of each blanket segment consists of a number of modular annular boxes through which the $\mathrm{Pb}-17 \mathrm{Li}$ flows in two poloidal passes. Ribs attached to the inner annular wall form the first wall cooling channel, allowing the coolant to flow at high velocity to keep the outer and inner walls 


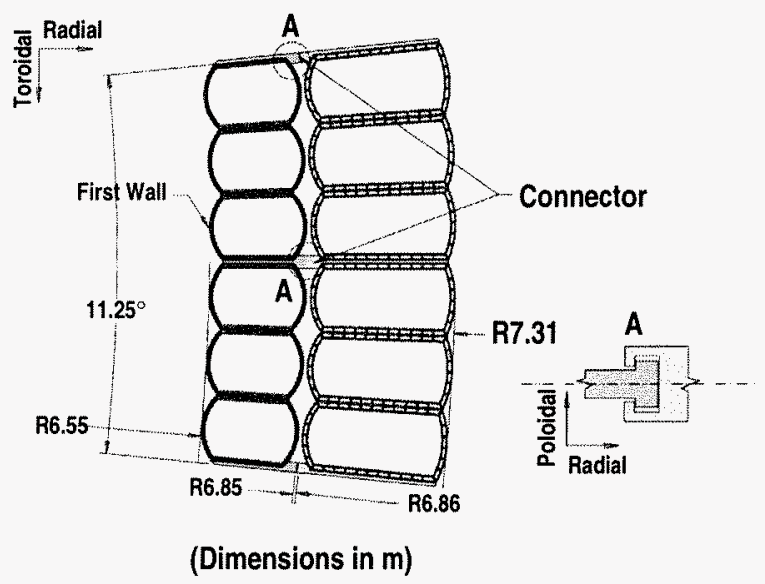

Fig. 4. Cross-section of ARIES-AT outboard FW/blanket segment.

cooled. The coolant then makes a U-turn at the top of the poloidal module and flows very slowly as it makes a second pass through the large inner channel where the $\mathrm{Pb}-17 \mathrm{Li}$ is heated up volumetrically and then exits at high temperature. This flow scheme enables operating $\mathrm{Pb}-17 \mathrm{Li}$ at a high outlet temperature of $1100^{\circ} \mathrm{C}$, while maintaining the blanket $\mathrm{SiC}_{\mathrm{f}} / \mathrm{SiC}$ composite and $\mathrm{SiC} / \mathrm{Pb}-17 \mathrm{Li}$ interface at a lower temperature of $\sim 1000^{\circ} \mathrm{C}$. The first wall consists of a $4 \mathrm{~mm} \mathrm{SiC/SiC}$ structural wall on which a $1 \mathrm{~mm} \mathrm{CVD} \mathrm{SiC} \mathrm{armor}$ layer is deposited, with a maximum $\mathrm{SiC}$ first wall temperature of $996^{\circ} \mathrm{C}$.

5. The $\mathrm{V} / \mathrm{Li} / \mathrm{He} \mathrm{FW} /$ blanket was evaluated for the US DEMO reactor design [7]. It was developed to take advantage of the excellent compatibility between V-alloy and lithium. It is cooled by high pressure helium tubes imbedded in a pool of lithium as shown in Fig. 5. This avoids the MHD concern of circulating lithium in a metallic structure. The high helium pressure of $18 \mathrm{MPa}$ was selected for the use of CCGT, which gives a thermal efficiency of $47 \%$ at a relatively low coolant outlet temperature of $650^{\circ} \mathrm{C}$, which is limited by the maximum allowable operating temperature of V-alloy. Key design parameters are presented in Table 1. To avoid the concern of accidental high helium pressure in the blanket, a pressure release burst disk design will also need to be incorporated into the blanket module design. This FW/blanket was designed to handle neutron and surface loading of 2.9 and $0.34 \mathrm{MW} / \mathrm{m}^{2}$, respectively. The basic concern for 


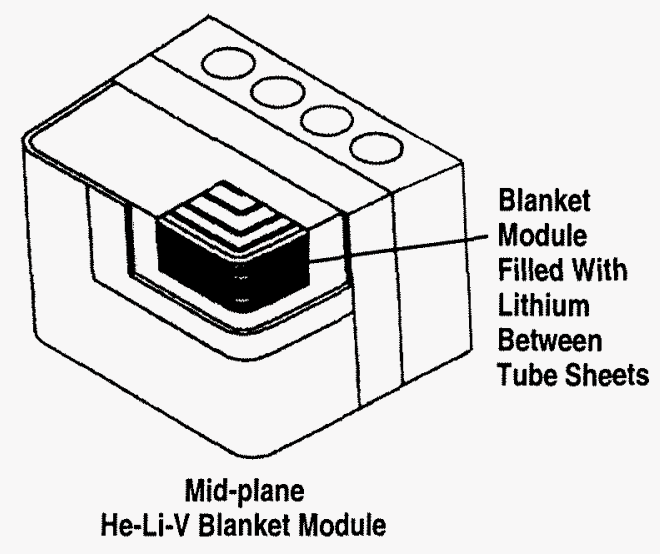

Fig. 5. V/Li/He FW/blanket module.

this design is the interaction of coolant impurities (e.g. $\mathrm{O}$ and $\mathrm{H}$ ) with the $\mathrm{V}$-alloy. The oxygen impurity concern can be handled by continuous purification of the helium in the coolant circuit. Relying on the affinity of lithium to hydrogen, the possible chemistry control of hydrogen contained in the $\mathrm{V}$-alloy under the presence of a large amount of lithium has not been investigated. A higher performance version, and with the change of the stagnant liquid breeder from $\mathrm{Li}$ to $\mathrm{LiPb}$ was also investigated [8]. With changes in geometric arrangement of the blanket segmentation this design was shown to be able to handle average neutron and surface heat flux of 8 and $2 \mathrm{MW} / \mathrm{m}^{2}$, respectively. But the key issue of protecting the vanadium alloy from hydride formation due to the high partial pressure of tritium in $\mathrm{LiPb}$ was not addressed.

6. The $\mathrm{W} / \mathrm{Li} / \mathrm{He}$ design is an extension of the $\mathrm{V} / \mathrm{Li} / \mathrm{He}$ design by changing the structural material from $\mathrm{V}$-alloy to $\mathrm{W}$-alloy [9]. The blanket configuration is shown in Fig. 6. This design avoids the compatibility issue between helium impurities and V-alloy. It was designed to handle neutron wall and surface loading of $7 \mathrm{MW} / \mathrm{m}^{2}$ and $2 \mathrm{MW} / \mathrm{m}^{2}$, respectively. Key design parameters of this design are presented in Table 1. Because of the projected high temperature capability of W-alloy with a coolant outlet temperature of $1200^{\circ} \mathrm{C}$, at a coolant pressure of $12 \mathrm{MPa}$, the CCGT thermal efficiency is $57.5 \%$. The tritium breeding of this design is aided by the $(n, 2 n)$ reaction of the $W$, and adequate 


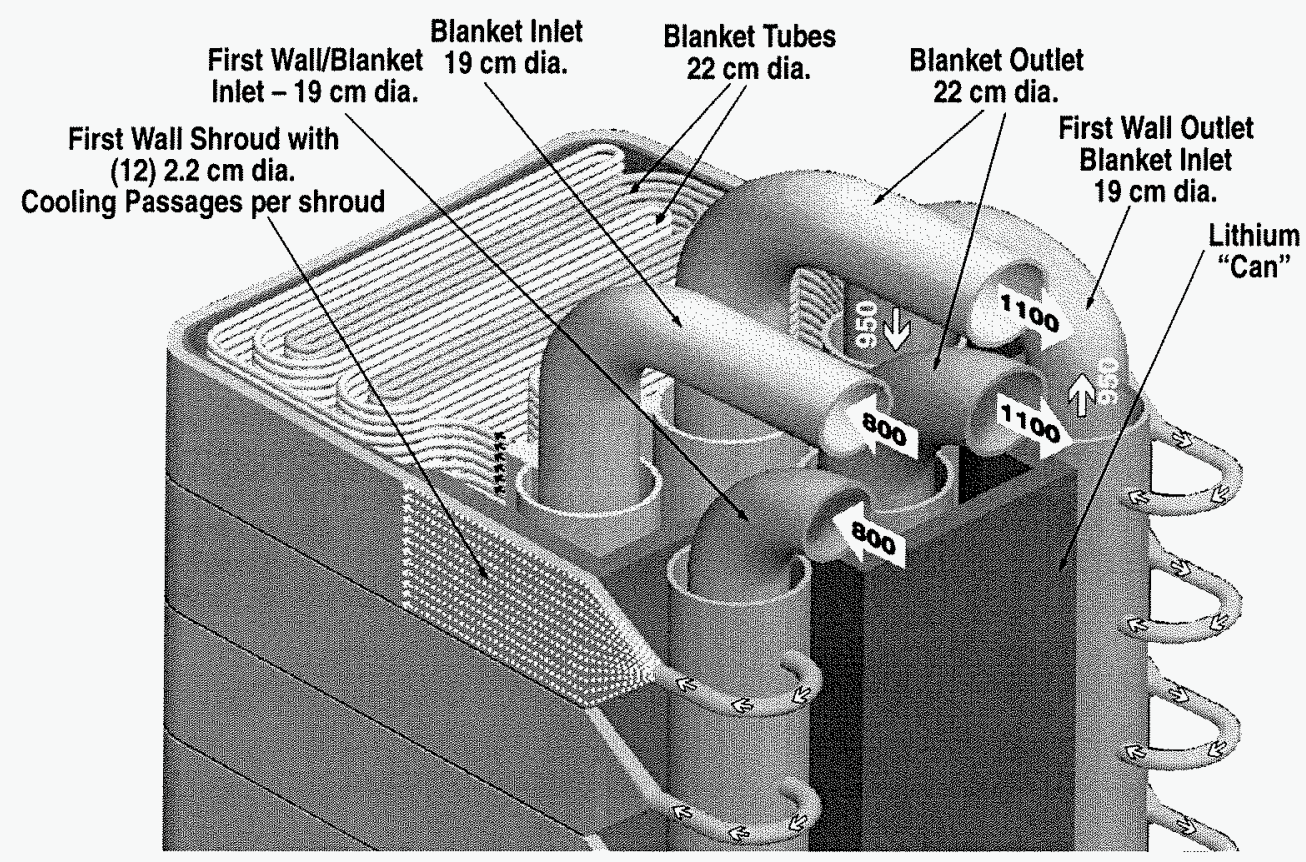

(Temperature in ${ }^{\circ} \mathrm{C}$ )

Fig. 6. W/Li/He FW/blanket module.

tritium can be produced. The critical issues for this design relate to joining and fabrication techniques for W-alloy. Both V-alloy and W-alloy helium cooled designs also have the basic issues of large helium-void fraction in the blanket and the requirement for a large coolant plenum at the back of the blanket as shown in Fig. 6.

7. To achieve high thermal performance at high power density, the EVOLVE W-alloy FW/blanket concept proposes to use the vaporization of lithium as the active coolant with a lithium vapor outlet temperature of $1200^{\circ} \mathrm{C}$, leading to a helium CCGT efficiency of $\sim 58 \%$ [10]. This design operates at a low system pressure of $0.037 \mathrm{MPa}$. Key design parameters are presented in Table 1. The pumping of the lithium circulation in the FW tubes is performed by capillary suction as shown in Fig. 7. For the pumping of liquid Li, the basic design criterion is that the capillary pressure at the first wall must overcome the sum of all frictional and MHD pressure losses in the FW/blanket coolant loop. As shown in Fig. 7 the proposed design has a first wall tube diameter of about $6 \mathrm{~cm}$, a lithium channel width of about $2 \mathrm{~mm}$ and a capillary opening of $0.5 \mathrm{~mm}$. The blanket can be 


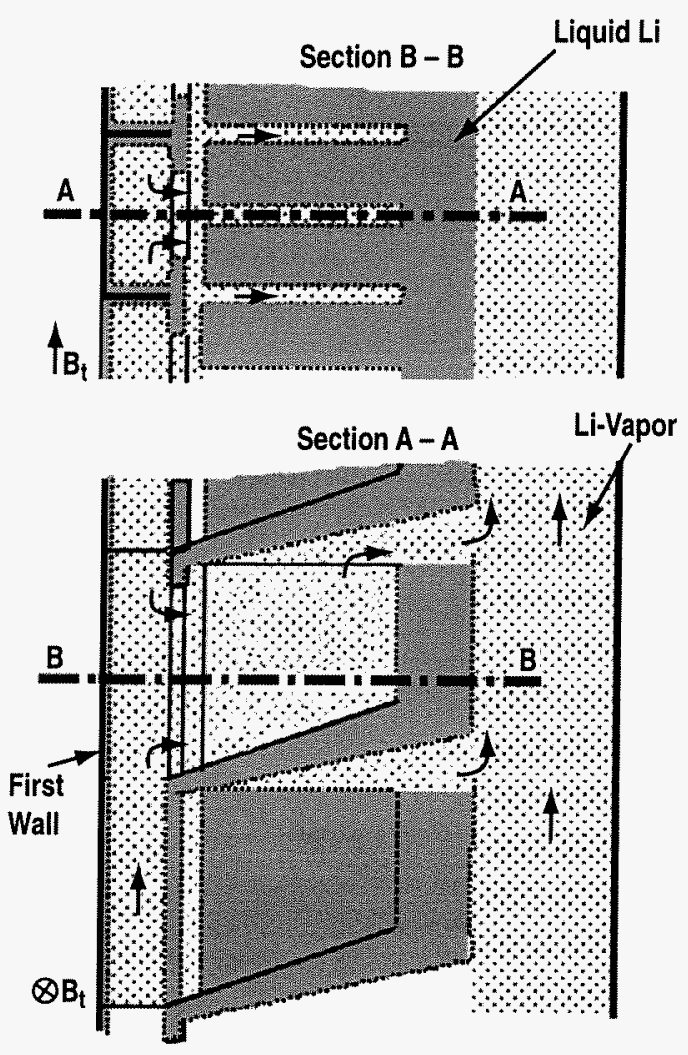

Fig. 7. The transpiration-cooled FW/blanket schematic (section B-B is the top view and section A-A is the side view of the design).

cooled by an extension of the FW Li-vaporization cooling as shown in Fig. 7, or it can be cooled by the boiling of lithium as shown in Fig. 8. For the capillary vaporization cooled option, the lithium slabs in the blanket are held in walls with capillary openings. For this blanket option, the characteristic dimensions are then determined based on the superheating of the lithium. These are passively cooled FW/blanket options. Basic issues of these designs are the concern of $\mathrm{W}$-alloy component fabrication, the MHD effects on the capillary cooling of lithium.

Both W-alloy designs have high afterheat, but this potential safety issue could be handled by the incorporation of passive coolant loop designs [10]. Furthermore, due to the generation of $108 \mathrm{mRe}$ from nuclear interaction with base elements in the $\mathrm{W}$-alloy, the goal of class-C waste disposal at the end of reactor life cannot be satisfied [11]. 


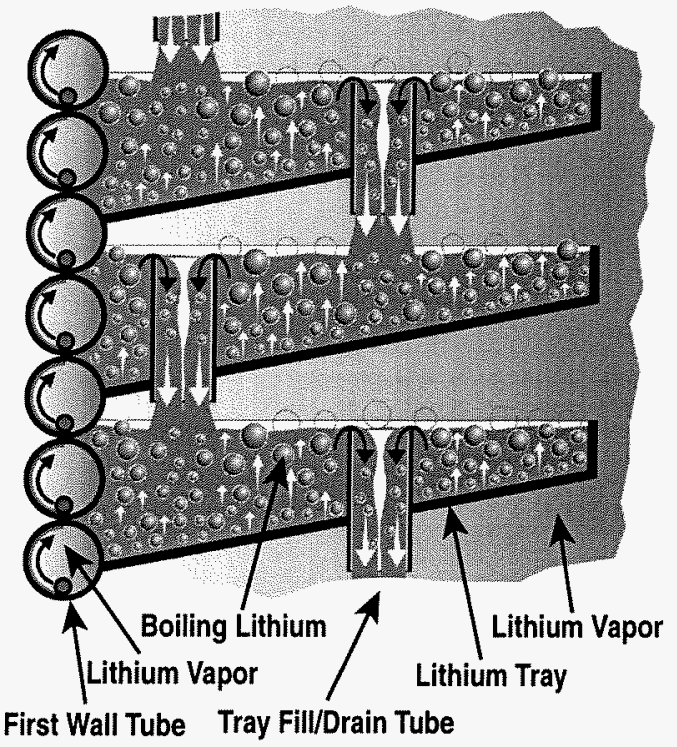

Fig. 8. Schematic of EVOLVE FW and boiling blanket concept.

8. The FFHR-2 FW/blanket design is proposed for the helical reactor design [12]. It uses $\mathrm{V}-4 \mathrm{Cr}-4 \mathrm{Ti}$ alloy as the structural material and Flibe $\left(\mathrm{LiF}-\mathrm{BeF}_{2}\right)$ as the coolant and tritium breeder. Key design parameters are presented in Table 1. The advantages of Flibe are: stable material with air and water, low electrical conductivity and low tritium inventory. To reduce the stress concentration, the first wall structure has a semi-circular shape and the Flibe is circulated in a zigzag pattern through the Be pebbles, as shown in Fig. 9. The coolant has an inlet pressure of $0.6 \mathrm{MPa}$ and the first wall temperature is $600^{\circ} \mathrm{C}$. With a Li-6 enrichment of $50 \%$, the local tritium breeding ratio is 1.4 , which should be adequate when extended to the overall power reactor design. Due to the low thermal conductivity of Flibe at $1 \mathrm{~W} / \mathrm{m}-\mathrm{K}$, a porous medium of $\mathrm{V}$-alloy was recommended for heat transfer enhancement and reduced pressure drop [13]. Compared to a smooth tube, the Nu number can be increased from a value of 5.7 to the range of $30-60$, depending on the velocity through the porous medium [13]. A variation on this design could be the replacement of $\mathrm{V}$-alloy with advanced ferritic steel or $\mathrm{SiC}_{\mathrm{f}} / \mathrm{SiC}$ composite structural material. Another key issue, which is being addressed in the JUPITER-II program [14], is the compatibility 


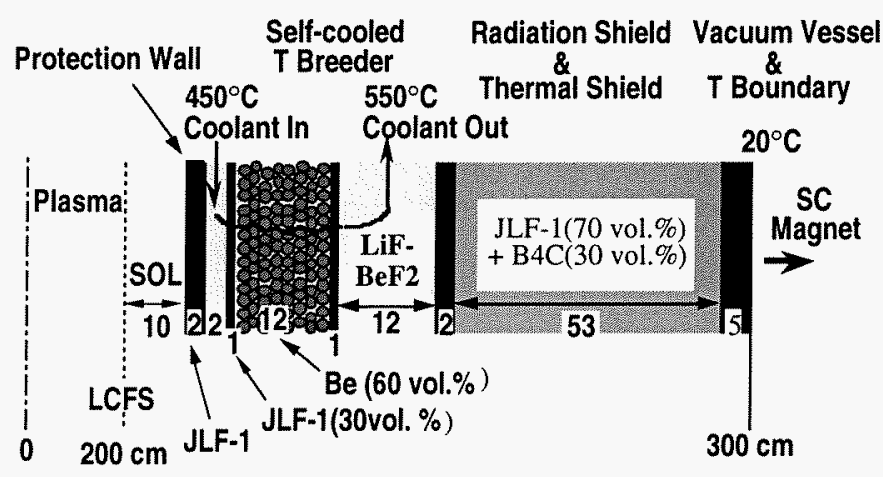

Fig. 9. The blanket structure used in the FFHR-2 thermo-mechanical analysis.

of Flibe with the selected structural materials including the issue of high partial pressure of tritium in Flibe. 


\section{NECESSARY AND DESIRABLE ATTRIBUTES ASSESSMENT}

In the following we will assess the eight FW/blanket designs by considering the necessary and desirable attributes for power reactor designs. The goal is not to provide critical review of any specific FW/blanket design, but to identify general trends in order to provide directions for future research.

\subsection{Adequate tritium breeding}

All designs summarized above can potentially provide adequate tritium breeding with at least the use of Li-6 enrichment or Be as the neutron multiplier. Solid breeder and Flibe breeder designs will require the use of a Be neutron multiplier and, accordingly, will have to be designed to accommodate the irradiation swelling and tritium inventory of the Be-neutron multiplier. Li-6 enrichment may also be needed for these designs. Li-17Pb designs can be designed with or without the use of Li-6 enrichment. V-Li/He and EVOLVE designs are the only two that can provide adequate tritium breeding without the use of Li-6 enrichment or a neutron multiplier.

\subsection{Structural design}

With a thin first wall thickness between 2 to $5 \mathrm{~mm}$, all designs can be shown to satisfy the structural design criteria of the given material under steady state operation. The key uncertainty is the credibility of the given structural material design data since none of the material has been tested under high $14 \mathrm{MeV}$ fusion neutron fluence conditions. Even though significant effort has been devoted to the extrapolation of design properties based on fission irradiation data [15], fusion irradiation data will still be needed. The degree of extrapolation of design data, in terms of higher to lower credibility, could be ranked in the order of $\mathrm{V}$-alloy, $\mathrm{W}$-alloy and $\mathrm{SiC} / \mathrm{SiC}$ composite material. 


\subsection{Thermal hydraulics}

Thermal hydraulics designs will mainly depend on the blanket configuration, thermal power input, selected structural and FW/blanket coolant materials. Helium coolant options are designed with small channel tubes in order to withstand the high pressure of $8-18 \mathrm{MPa}$. Pb-17Li and Flibe coolants can operate at much lower system pressure in the range of 1 to $1.5 \mathrm{MPa}$. The lowest pressure design is the vaporized lithium EVOLVE design, which uses a coolant pressure of $0.037 \mathrm{MPa}$. All selected designs have avoided the large MHD pressure drop when liquid metal is circulated at high speed in metallic channels in a magnetic confinement system. It should be noted that due to the low thermal conductivity of Flibe at $1 \mathrm{~W} / \mathrm{m}-\mathrm{K}$, in order to remove the relatively low heat flux of $0.1 \mathrm{MW} / \mathrm{m}^{2}$, an extended heat transfer option like the use of a porous medium is necessary for the helical reactor FFHR-2 design [13].

\subsection{Material issues}

For the designs that we have reviewed, it is obvious that we are investigating materials with three key properties: high strength, high allowable maximum temperature and low activation. W-alloy alloy does not have the low activation property, but it has projected high strength and high thermal conductivity of $85 \mathrm{~W} / \mathrm{m}-\mathrm{K}$ at high temperature of $1300^{\circ} \mathrm{C}$. This led to the low pressure vaporized-lithium cooled design.

The key concerns for the $\mathrm{V}$-alloy, $\mathrm{W}$-alloy and $\mathrm{SiC}_{\mathrm{f}} / \mathrm{SiC}$ materials are mechanical and thermal property degradation under high fusion neutron fluence. It is obvious that material irradiation facilities such as the International Fusion Materials Irradiation Facility (IFMIF) [15] and volumetric neutron source (VNS) [16] should be constructed and made available for fusion materials qualification. Correspondingly, fusion relevant design codes for metallic and ceramic composite materials will have to be developed.

Furthermore, compatibility issues under a fusion environment for solid-breeder/Be/SiC, $\mathrm{Pb}$-17Li/SiC, He-impurities/V-alloy, He-impurities/W-alloy, Li/W-alloy, $\mathrm{Pb}$-17Li/V-alloy, and 
Flibe/V-alloy systems, covering the FW/blanket options that we are considering, will have to be addressed before we can even consider the question of component lifetime.

Feasibility issues of component fabrication, especially for $\mathrm{SiC}_{\mathrm{f}} / \mathrm{SiC}$ and $\mathrm{W}$-alloy materials, will have to be addressed. Efforts have been initiated for the ceramic $\mathrm{SiC}_{\mathrm{f}} / \mathrm{SiC}$ composite material [18]. Similarly, the fabrication development on V-alloy through the more conventional metallic alloy development path has also been initiated [19].

It should be noted that since we have no operation experience with these advanced FW/blanket designs, we are in no position to answer the very important questions of component lifetime and availability. Therefore, we cannot underscore enough the importance of initiating the integrated first wall and blanket testing under the ITER program [20] and the fusion development facility (FDF) [21].

\subsection{High power density}

As we can see from Table 1, the average neutron wall loading covers the range of 3 to $8 \mathrm{MW} / \mathrm{m}^{2}$ for tokamak reactors and has a lower value of $1.7 \mathrm{MW} / \mathrm{m}^{2}$ for the helical reactor. At least for the tokamak reactors with the output power range of $1-2 \mathrm{GW}(\mathrm{e})$, the selected FW/blanket designs cover the optimum neutron wall loading range of $4-7 \mathrm{MW} / \mathrm{m}^{2}$ when the cost of electricity is taken into consideration [22].

\subsection{Safety and environmental impacts}

\subsubsection{Low tritium inventory and favorable tritium control}

For lithium breeder blanket options, because of the affinity of lithium to hydrogen and the proposed low concentration of tritium in the lithium loop, the inventory of tritium for these designs should be low and its routine release can be kept to a minimum. Similarly, solid breeders have the option of controlling the operating characteristics by the use of a purge flow stream. Therefore the concerns of tritium inventory and release in solid breeder material could also be 
controlled. However, when $\mathrm{Be}$ is used as the neutron multiplier, the potential tritium inventory and subsequent release remain to be addressed. For breeding materials like $\mathrm{Pb}-17 \mathrm{Li}$ and Flibe, due to their low solubility of hydrogen, the control of routine and accidental tritium release will be necessary. Furthermore, when the structural material is taken into account, the potential tritium inventory in $\mathrm{SiC}_{\mathrm{f}} / \mathrm{SiC}$ composite, $\mathrm{V}$ and $\mathrm{W}$-alloys is still uncertain.

\subsubsection{Low afterheat, passive safety and minimum radioactivity release}

With the exception of W-alloy, the reviewed designs have relatively low afterheat, which would make it easier to fulfill the goal of passive safety. On the other hand, even with the much higher afterheat from $\mathrm{W}$-alloy, built-in natural circulation loops can be used to maintain passive safety under the loss of power accident, while meeting the dose limit of $10 \mathrm{mSv}$ at the site boundary during a worst-case accident scenario [10]. For designs with high pressure helium, rupture disks in the coolant circuit connected to a discharge vessel will be required to protect the blanket from accidental pressurization in case of heat exchanger failure. An example of this is given in the A-HCPB design [3].

When $\mathrm{Pb}-17 \mathrm{Li}$ is used as the blanket coolant the formation of ${ }^{210} \mathrm{Po}$, which has a very low activity limit of $0.001 \mathrm{wppb}$, should be controlled. Since ${ }^{210} \mathrm{Po}$ is generated from ${ }^{209} \mathrm{Bi}$ as a subsequent nuclear reaction and decaying beginning from ${ }^{208} \mathrm{~Pb}$, the recommendation has been the on-line removal of Bi during blanket operation [23].

\subsubsection{Class-C waste disposal}

With the exception of $\mathrm{W}$-alloy designs, we have been considering low activation FW/blanket designs. The key is the necessary control of selected impurities, e.g. Nb to less than 1 wppm. Both $\mathrm{SiC}_{\mathrm{f}} / \mathrm{SiC}$ and $\mathrm{V}$-alloy at the end of a 40 full power year life, and after a waiting period of ten years, can be treated as class- $\mathrm{C}$ waste. $\mathrm{SiC}_{\mathrm{f}} / \mathrm{SiC}$ has the disadvantage of having to dispose off a larger volume of low-level waste than for a V-alloy design. For metallic structures, recycling of irradiated material has been considered as a viable option for waste disposal [24], leading to a 
much-reduced amount of waste to be considered as high-level waste. For W-alloy, due to the formation of Re from the W metal, W-alloy designs at the end of life will have a waste disposal ratio exceeding the qualification as class- $\mathrm{C}$ waste [11].

\subsection{High power conversion efficiency}

Table 1 shows that all design options presented can meet the high thermal performance requirement with the use of Brayton cycle power conversion option. High thermal efficiency of $>43 \%$ is projected. Higher efficiency of $>57 \%$ can be reached either by the use of high temperature W-alloy structural material $[9,10]$, or by the innovative routing of the coolant [6] when $\mathrm{SiC}_{\mathrm{f}} / \mathrm{SiC}$ composite is used. In the future, parallel development of the advanced fusion FW/blanket and advanced Brayton cycle will be necessary [24].

\subsection{First wall coating and coupling with the divertor design}

For a tokamak reactor design, there is a trade-off between the first wall heat flux and the divertor heat flux. The FW/blanket designs will have to be coordinated with the proposed schemes for plasma detachment at the divertor, which is to reduce the peak divertor heat flux with the corresponding increase of the surface heat flux at the first wall, due to impurity radiation. Furthermore, there is still the active research area of material surface erosion at the divertor and the first wall. Presently, the physics of particle and energy transport in the scrape off layer and the layer just inside the last closed flux surface of the tokamak is far from understood. Preliminary results show that about equal contributions of impurities getting into the plasma core may be coming from the first wall and the divertor. Accordingly, we will have to increase our attention in the selection of suitable first wall coating material in order to maximize the first wall component lifetime with minimum erosion rate and yet, at the same time, only generate the amount of eroded material with acceptable atomic weight in coordination with the necessary high performance of the plasma. 


\subsection{Compatibility with plasma operation}

It should be noted that up to now the design of advanced FW/blanket designs have been focusing on key requirements and goals of high thermal performance at steady-state, low activation design and passive safety. Issues of reactor start-up, especially when liquid metal is utilized, and response to disruption have not been addressed. These issues will have to be assessed with increase depth when the coupling between plasma and reactor operating is better understood. Another area of design that will have to be incorporated in future advanced tokamak FW/blanket studies is the accommodation of passive and active plasma stabilization coils, which will be imbedded in the FW/blanket system. These sets of coils will also have major impacts on the nuclear performance, mechanical, electrical and thermal hydraulics designs. Even though some of these issues are being addressed by reactor design systems studies, the FW/blanket assessment community will have to be directly involved since these issues will have significant impacts on the performance and lifetime of our designs. 


\section{CONCLUSION}

Eight advanced high performance solid wall blanket concepts were reviewed. Innovative 'designs have been identified to simplify the mechanical design and reduce the operational system pressure. These designs have been focusing on satisfying performance requirements and goals on tritium breeding adequacy, high thermal performance and passive safety. Significant fabrication uncertainties remain when $\mathrm{SiC}_{\mathrm{f}} / \mathrm{SiC}$ composite and $\mathrm{W}$-alloy are proposed as structural materials. Basic fusion engineering design data on $\mathrm{V}$-alloy, $\mathrm{SiC}_{\mathrm{f}} / \mathrm{SiC}$ composite and $\mathrm{W}$-alloy materials are lacking, and this can only be addressed satisfactorily by $14 \mathrm{MeV}$ neutron experiments like IFMIF and integrated testing device like FDF. Using a device like ITER to provide preliminary FW/blanket testing will also be useful. In the near future, when the coupling between the plasma operations with the FW/blanket design becomes more matured, advanced FW/blanket design assessment should include the selection of suitable first wall coating material, plasma stabilization coil design, reactor startup and the handling of disruptions. These data will then help us to begin considering the issues of components lifetime and availability. 


\section{REFERENCES}

[1] L. Giancarli et al., "Progress in blanket designs using $\mathrm{SiC}_{\mathrm{f}} / \mathrm{SiC}$ composites," these proceedings.

[2] S. Nishio et al., "Conceptual design of advanced steady-state tokamak reactor," 18th IAEA Fusion Energy Conference, IAEA-CN-77/FTP2/14, Sorrento, Italy, (2000).

[3] L.V. Boccaccini, et al., "Advanced helium cooled pebble bed blanket with $\mathrm{SiC} / \mathrm{SiC}$ as structural material," Fusion Engineering and Design 49-50 (2000) 491-497.

[4] H. Golfier, et al., "Performance of the TAURO blanket system associated with a liquidmetal cooled divertor, "Fusion Engineering and Design 49-50 (2000) 559-565.

[5] I. Cook, Fusion Engineering and Design 25 (1994) 179.

[6] A.R. Raffray, et al., "ARIES-AT blanket and divertor," Fusion Technology, Vol. 39, (2001) 429-433.

[7] C.P.C. Wong et al., "Evaluation of U.S. demo helium-cooled blanket options," Proc. 16th IEEE/NPSS Symp. on Fusion Engineering, September 30-October 5, 1995, Champaign, Illinois, Vol. 2, p. 1145 (Institute of Electrical and Electronics Engineers, Inc. Piscataway, New Jersey, 1996).

[8] C.P.C. Wong et al., "The low aspect ratio design concept - possibility of an acceptable fusion power system," Proc. 17th IEEE/NPSS Symp. on Fusion Engineering, October 610, 1997, San Diego, California, Vol. 2, p. 1051 (Institute of Electrical and Electronics Engineers, Inc. Piscataway, New Jersey, 1998).

[9] C.P.C. Wong et al., "Helium-cooled refractory alloys first wall and blanket evaluation," Fusion Engineering and Design 49-50 (2000) 709-717.

[10] C.P.C. Wong et al., "Evaluation of the tungsten alloy vaporization lithium first wall and blanket concept," Fusion Technology, Vol. 39, part 2, (2001) 815. 
[11] K. McCarthy et al., "Comparison of the safety and environmental characteristics of refractory alloys under consideration in APEX," Fusion Technology, Vol. 39, (2001) 951-955.

[12] A. Sagara et al., "Design and development of the Flibe blanket for helical-type fusion reactor FFHR," Fusion Engineering and Design 49-50 (2000) 661-666.

[13] S. Chiba et al., "Heat transfer enhancement for a molten salt Flibe channel," Fusion Technology Vol. 39, (2001) NEED PAGE NUMBER.

[14] D.K. Sze et al., "FliBe assessment," Fusion Technology, Vol. 39, part 2, (2002) 747.

[15] S.J. Zinkle, N.M. Ghoniem, "Operating temperature windows for fusion reactor structural mateials," Fusion Engineering and Design 51-51 (2000) 55-71.

[16] K. Ehrlich et al., "International strategy for fusion materials development," J. Nucl. Mater. 283-287 (2000) 79-88.

[17] M. Abdou et al., "Results of an international study on a high-volume plasma-based neutron source for fusion blanket development," Fusion Technology, Vol. 29, (1996) 1-57.

[18] A. Gasse, G. Aiello, L. Giancarli, G. Le Marois, J.F. Salavy, J. Szczepanski, Progress on $\mathrm{SiC} / \mathrm{SiC}$ structures joining techniques and modeling for design analysis, Proc. 20th Symp. on Fusion Technology, 1998, Marseille, France p. 1235-1238 (Association EURATOMCEA, Saint Paul Lez Durance, 1998).

[19] W.R. Johnson and J.P. Smith, "Fabrication of a $1200 \mathrm{~kg}$ ingot of V-4Cr-4Ti alloy for the DIII-D radiative divertor program," J. Nucl. Mater. 258-263 (1998) 1425-1430.

[20] R. Aymar, "ITER FEAT-the future international burning plasma experiment overview," Nucl. Fusion 41, No. 10 (2001) 1301.

[21] J. Wesley and R.D. Stambaugh, "Critical technology issues and development requirements for a fusion development facility," Fusion Technology, Vol. 39, part 2, (2001) 473.

[22] C.P.C. Wong, "Neutron wall loading of tokamak reactor," J. Nucl. Mater. 283-287 (2000) 588-592. 
[23] D. Henderson et al., "Activation, decay heat, and waste disposal analysis for the ARIES-AT power plant," Fusion Technology, Vol. 39, (2001) 444-448.

[24] E. T. Cheng, "Application of SEAFP waste recycling and clearance strategies to ITER," Fusion Engineering and Design 51-52 (2000) 485-491.

[25] R. Schleicher et al., "An assessment of the Brayton cycle for high performance power plants," Fusion Technology, Vol. 39, part 2, (2001) 823. 


\section{ACKNOWLEDGMENT}

Work supported by U.S. Department of Energy under Contract No. DE-AC03-98ER54411. 